\title{
Teaching Accounting in English in Higher Education - Does the Language Matter?
}

\author{
Huan Cai ${ }^{1}$, Meining Wang ${ }^{1} \&$ Yingmei Yang ${ }^{2}$ \\ ${ }^{1}$ School of English for International Business, Guangdong University of Foreign Studies, Guangzhou, China \\ ${ }^{2}$ School of English Education, Guangdong University of Foreign Studies, Guangzhou, China \\ Correspondence: Meining Wang, School of English for International Business, Guangdong University of \\ Foreign Studies, Guangzhou, China. Tel: 86-20-3620-9305. E-mail: 199210407@oamail.gdufs.edu.cn
}

Received: January 9, 2018 Accepted: February 13, 2018 Online Published: February 15, 2018

doi: 10.5539/elt.v11n3p50 URL: http://doi.org/10.5539/elt.v11n3p50

\begin{abstract}
Learning business related courses, especially accounting, in English is a challenge for many Chinese students. The purpose of this study is to provide some insights into the role of the language in accounting learning. We investigate this issue in the program of Teaching Business Related Courses in English for undergraduate students at Guangdong University of Foreign Studies. Accounting courses in English at GDUFS are taught to two different groups: English majors with higher English proficiency who are required to receive 2 years of intensive training in listening, speaking, reading and writing before taking the accounting course in English and non-English majors who do not receive the same level of English training as English majors do. We find that there is no direct significant relationship between accounting learning and students' English proficiency but we do find a strong correlation between students' analytical ability and their accounting learning instructed in English. We also find that motivation, specifically students' clear career path in the accounting field, plays an important role in determining their performance in accounting learning. The findings in this paper have meaningful implications for the feasibility of teaching non-English majors accounting in English and for designing a good learning environment in English educational settings.
\end{abstract}

Keywords: immersion teaching, business courses, influencing factors, role of language

\section{Introduction}

With the increasing globalization of business cooperation, higher education in China is expected to provide workforce to the more fiercely competitive international environment. Well aware of the urgency of producing foreign language professionals with interdisciplinary knowledge at universities, the Chinese Ministry of Education clearly pointed out as early as 2001 in its policy directives that it is necessary to promote other disciplinary training instructed in English (or other foreign languages) in a university, requiring that within three years the number of a given program's core courses that are instructed in a foreign language or bilingually is expected to take up 5\% to $10 \%$ of all the courses under the program. In 2015, the State Council, China's cabinet, promulgated the Overall Plan for Coordinated Development of World-class Universities and First-class Disciplines, which put forward higher requirements on Chinese universities for their comprehensive strength, academic disciplines and the training of first-class global-minded graduates. At present, there are more than 200 universities in the world that have established teaching and research units in business English and more than 800 Chinese universities that offer business English programs or courses (Zhu, 2010). These tertiary business English programs in China vie to offer business courses with English as the language of instruction (Guo, 2007). Evolving from the total immersion teaching methodology abroad, this English-only teaching in China is also classified by Chinese scholars (Cai, 2005) as English immersion teaching, and this term will be adopted as such throughout this paper.

English immersion teaching for business students is believed to have a significant impact on their knowledge structure. But there are not many studies in investigating whether it may impair the students' in-depth understanding of business related courses (Wang, 2015; Cai, 2011) or it may enhance students' English proficiency while their level of understanding of business-related contents is maintained (see Guo, 2007; Zhu, 2010; Chang and Liu 2014). Testing the hypothesis of the effectiveness over English immersion teaching may 
have meaningful policy implications for the Chinese Ministry of Education and universities at large in terms of the way to enhance the performance of higher education and the types of students to be produced.

This paper closely examines the role language proficiency plays in understanding the content of accounting course and to investigate what may influence accounting learning. It adds to the existing literature and extends the previous studies in the following five aspects: 1) It applies the empirical research method by conducting univariate tests and regression analysis; 2) The sample size used in this paper is larger than those used in most related researches. We include about 80 students each in the control group and experiment group over the period 2010-2016, making our sample size at 1104 students; 3) The comparison between the two groups is clear and valid in terms of English proficiency. Students in the control group are English majors, who have been trained English intensively for 2 years before taking business related courses in English while students in the experiment group are non-English majors, which means they don't have as much intensive training in English; 4) The teacher of accounting for both groups is the first author herself, which will exclude the endogenous issue of teacher qualifications; 5) A comprehensive financial case study is presented to both groups over the 7 years and is graded by the same teacher to evaluate the students' English reading comprehension and analytical ability.

This study reveals that students of English major do not show better performance in accounting learning in English than those of non-English major. Furthermore, the analytical skills of the students significantly and positively affect their performance in accounting learning throughout the semester for both groups. Our findings further indicate that students' performance is significantly affected by their motivation of choosing accounting as their future career.

This paper is organized as follows. Following Introduction, Part 2 reviews the literature on immersion teaching. Part 3 develops hypotheses and Part 4 describes the data and measurement metrics. Part 5 tests the hypotheses and discusses the findings and discussions. Based on these, Part 6 summarizes the study and draws a conclusion of the paper.

\section{Literature Review}

There have already been studies on immersion teaching in general and English immersion teaching in particular. Furthermore, both international and Chinese researchers have also been trying to empirically explore its impact on student learning in various fields. The paper here will then first review relevant theories of immersion teaching followed by empirical studies of demographic variables on learning effects, both on the global scene and in the Chinese context.

\subsection{An Overview of Immersion Teaching}

Language immersion is defined as an approach of foreign language instruction in which the regular school curriculum is taught through the medium of the target language (Met, 1993). The foreign language here is not the subject of instruction; rather, it is the vehicle for content instruction (Met, 1993). Snow (1986) noted that immersion can be identified as the most intensive form of content-based foreign language instruction. The relative success of Canadian and U.S. language immersion programs has been the initial support for this approach (Genesee, 1985). With the recognition of the importance of teaching academic content in language courses, Content-based instruction (CBI) has been increasingly employed in many different foreign or second language learning contexts and its benefits have also been supported by numerous studies (Grabe and Stoller, 1997). In CBI, language learners develop linguistic skills in the target language, which can be a bridge to access content knowledge of a specific subject matter in a natural process. Swain (1996) indicated that "Integration of content and language instruction covers all aspects of language knowledge and the four language skills". Snow, Met, and Genesee (1989) also pointed out that effective language learning can be promoted by integration of language and meaningful social and academic content. They went on to emphasize that interesting and important content greatly motivates language learners because language learning incidentally occurs when learning about the content, for example, in immersion classes.

\subsection{Demographic Variables on Learning Effects of Immersion Teaching}

In empirical studies, scholars focus on the influence of demographic variables such as gender, age, working experience, education level and marital status on learning effects of immersion program.

J. Cummins (1983) finds through French Immersion Teaching program in Canada that immersion teaching can improve students' second language proficiency. He also finds out that older participants outperformed the younger ones in improving their ability of second foreign language.

Macaro (2013) studies the impact of learner's age on the attitude and effect of language immersion teaching. He tested through 798 participants of which 311 were college students and 487 were elementary school students. 
The research shows that age plays a critical role in determining the study effects of immersion teaching and college students are more likely to adapt to English teaching than primary school students. The author suggests that the probable reason might be that college students are more experienced in language learning or that they have stronger knowledge acceptance.

\subsection{English Immersion Teaching on the Global Scene}

As English immersion teaching is being applied across developing countries, scholars have been exploring the feasibility and actual effect of this approach. Take the educational reform at South Korean universities as an example. Some scholars there argue that teachers and students are not adequately prepared in their language skills and teaching strategies (Bae, 2011). Others emphasize the necessity of sufficient preparation so that effective teaching methods should already be ready before students enter the university so as to enhance students' proficiency, and English immersion teaching should be incrementally applied instead of having all the first-year students uniformly being taught in that approach without consideration of students' individual differences (Kang, 2012).

Rea-Dickins' study of students in Zanzibar, Tanzania, which assesses their performance in mathematics, biology and chemistry under three different teaching modes (with native language, bilingual or English-only as the language of instruction respectively) reveals that students under English immersion teaching (i.e. the third mode) do not enjoy an advantage but instead experience some academic difficulties as in dealing confidently with learning and taking exams. Jiménez-Castellanos has studied the performance of pupils with Spanish as their native tongue under English immersion teaching mode. His four-year longitudinal study observed through data analysis their performance in English vocabulary, phonological awareness, fluency in reading, English reading ability and general language from the time when they entered kindergarten till grade three in primary school (Jiménez, 2014). The study found that compared with their counterparts in the control group, students under English immersion teaching did not get to such a level of progress and development as expected for their age and grade.

\subsection{English Immersion Teaching in the Chinese Institutions of Higher Learning}

As a new pedagogical method in Chinese universities, English immersion teaching also attracts the attention of scholars in China, who are interested in its applicability in the Chinese context, particularly in exploring whether this mode of teaching may affect the students' in-depth understanding of business related courses or it may enhance students' English proficiency while their level of understanding of business-related contents is maintained. They also want to understand what factors may affect the effectiveness of this English immersion teaching.

Wang (2015) observed students of the School of Management at Shanghai University of Engineering Science for five academic years from 2010 to 2014 who took "Econometrics", "Futures and Options" and "Operations and Management of Commercial Banks" and with empirical Logit analysis he noticed some decrease in students' overall GPA after English immersion teaching was adopted.

Xing (2006) conducted a satisfaction survey of 244 third-year university students under the English immersion teaching methodology in which only $9.84 \%$ said that it improved both their program-specific knowledge and their English proficiency when asked "What benefits do you think you have gained from receiving English immersion teaching?" while other students said that the benefits were "Not much" or simply "None".

However, there are also considerable researches that argue for the positive role that English immersion teaching plays. After comparing students of Business English major at Guangdong University of Foreign Studies with students of other foreign language majors at GDUFS and those at other foreign language universities across China in terms of TEM-8 (Test for English Majors-Band 8) scores and job placement rate, Guo (2007) and Zhu (2010) found that the former outperformed the latter and they argued that the better performance of the former was due to the fact that English immersion teaching was carried out for those students of business English major.

$\mathrm{Lu}$ (2008) found that thanks to the adoption of English immersion teaching in the program-specific courses, their students kept ranking first across the university on the average CET-4 (College English Test-Band 4)score, excellence rate, pass rate, listening, reading and writing. With a strong English proficiency, these graduates are very popular with the corporate world.

Chang and Liu (2014) conducted an assessment of the effectiveness in English immersion teaching through quantitative regression on a sample of 133 students of financial management major from the School of Finance, Guangdong University of Foreign Studies. They found that English immersion teaching significantly improved students' performance in standardized tests of CET-4 and CET-6, with the most significant increase in listening 
comprehension, followed by reading and writing. Therefore they argued that English immersion teaching played a significant positive role in practice.

As for the factors contributing to the effectiveness in English immersion teaching, Cai (2011) interviewed 60 students at China's Fudan University who took the course of Public Relations and found that students who had passed CET-4 or above were academically ready for the English immersion teaching approach.

Intuitively, teachers play a role in English immersion teaching and may presumably affect its success (or failure). Therefore, some Chinese scholars have also studied their specific role in English immersion teaching. In her research, Du (2005) identified and analyzed the following five roles of teachers in English immersion teaching: instructor of the English language; disseminator of program-related content knowledge; provider of teaching and learning materials; facilitator of turning students' mind from language learning to program-related content learning; and promoter of the English language and culture and cultural exchange. $\mathrm{Hu}$ (2006) points out that teachers, who are invariably Chinese, may themselves experience difficulties in speaking of the English language in the process of English immersion teaching, thus adversely affecting the accuracy and breadth in teacher-student two-way communication and their use of the language. Hu also suggests that teachers emphasize English language teaching itself at the expense of imparting program-specific content knowledge. Chen (2009) also believes that teachers' inadequate proficiency is a critical issue in English immersion teaching and serious shortage of qualified teachers is a key factor that makes it difficult to promote immersion teaching. Therefore, it is not easy for universities to carry out English immersion teaching on some program-specific content courses. It is necessary to strengthen such pedagogical approach so as to foster a team of qualified teachers to meet the need.

\section{Hypotheses Development}

The students under the current study are second-year students enrolled by Guangdong University of Foreign Studies through National University Entrance Exam (Gaokao) at the same criteria. The participants fall in two groups: the control group who are business English majors with two years of intensive English training and the experiment group who are non-English majors under a dual bachelor degree program without intensive English training for the first two years of university. As mentioned in the literature review, scholars usually focus on the influence of demographic variables such as gender, age, working experience, education level and marital status on learning effects of immersion program. In this study, we strictly control the age, educational background and teaching hours for both groups. The accounting course for both groups, with 3 credit hours each week, was taught by the same teacher, who is the first author of this paper. The only difference between the two groups is the experience of intensive English language training after entering the university and therefore the non-English majors have not received intensive English training in listening, reading and writing. But they do have learned English for exam purposes in their junior and senior high school years. After entering university, they take 3-6 credit hours per week of English language-related courses mainly focused on extensive reading. Furthermore, accounting is an art as well as a science of knowledge, and Snow, Met, and Genesee (1989) argued that interesting and important content greatly motivates language learners because language learning occurs when they learn about the content in immersion classes. It is therefore expected the performance of accounting learning for both groups not to show significant difference in the current study and thus here is the first hypothesis to test:

\section{H1: There is no direct significant relationship between accounting learning and students' English proficiency at} university level.

What factors will influence accounting study instructed in English then? Accounting is sometimes considered an art since it requires the use of analytical skills and creative judgment. Although the content is not instructed in the native language, language learners develop linguistic skills in the target language which can be a bridge to access content knowledge of a specific subject matter in a natural process (Swain, 1996). It is thus expected that the factors that influence accounting learning won't be different no matter the teaching is instructed in English or native language. Hence here is the second hypothesis to test:

H2: There is a strong correlation between students' analytical ability and their performance in accounting learning that is instructed in English only.

The School of English for International Business (SEIB), Guangdong University of Foreign Studies is well-known for its program of teaching business course in English and for its great student employability upon graduation (Guo, 2007; Zhu, 2010). It started to offer a dual bachelor degree program in 2011 to students across the University with the same business course curriculum and same faculty. Under this program, students have to take additional credits of business courses besides those required by their own majors. The application received 
each year so far has kept exceeding the admission capacity. It is assumed that the strong interest in applying for the dual bachelor degree appears to serve as a response to intrinsic motivational needs toward personal development and occupational plan. Existing research has confirmed the relationship between intrinsic motivation and performance as being uniformly positive: The higher the intrinsic motivation in a task, the higher one's performance (Vallerand \& Ratelle, 2004; Gagne \& Deci, 2005; Tice, Baumeister, Shmueli \& Muraven, 2007). Hence here are two relevant hypotheses to test:

H3: Compared with students of English major, students of non-English major on a dual bachelor degree program have stronger occupational aspirations, thus stronger intrinsic motivation in dedicating themselves to the study of business courses instructed in English.

H4: The stronger the intrinsic motivation is, the better the students will perform in their study of business courses instructed in English.

\section{Methodology and Data Collection}

\subsection{Data}

We collect the data in Introduction to Accounting class taught by the first author over the years 2011-2017 from two different groups: English majors from SEIB and non-English majors on the dual bachelor degree Program from across the University. Altogether, we have a total of 1104 valid observations, of which English majors take up 519 and non-English majors take up 585.

The research targets in our study are second-year students who were enrolled by Guangdong University of Foreign Studies through National University Entrance Exam at the same enrollment criteria. However, English major students were required to receive 2 years of intensive English training, with an average of 12-16 credit hours per week in listening, speaking, reading and writing before taking the accounting course in English while non-English major students who seek the dual degrees didn't receive the same level of English training as English majors did and they took 3-6 credit hours per week of English language-related courses mainly focused on extensive reading.

The students' data, collected and kept by the first author, include the following:

1) Students' assessment, which is made up of scores on two quizzes, one case report and the final exam, taking up $20 \%, 30 \%$ and $50 \%$ of the whole assessment respectively. The two quizzes and the final exam each include both objective and open questions.

2) Case report. The score is based on how students respond to the case questions. One question tests how well they understand the case and the other two test their ability in applying what they have learned in class to analyzing the case. Reading comprehension, writing and analysis skill take up $20 \%, 20 \%$ and $60 \%$ of the total score respectively. According to the percentage allocation, we can calculate the contribution of each section to the final assessment: Reading makes up a total of 6 points, writing 6 points and analytical skill 18 points.

3) Survey. A survey was conducted by the teacher at the end of each semester. The survey mainly investigates the students' career plan in the accounting field. The closed question "Will you take accounting-related job as your future career?" is asked and the 5-level Likert Scale is applied in measuring the strength of motivation where 5 stands for "strongly agree " and 1 stands for "strongly disagree".

\subsection{Methodology and Measurement}

This research mainly discusses the role of language in accounting learning and investigates factors that may affect accounting learning instructed in English. We use the data of 1104 students' assessment information in their semester-long accounting learning and the survey information of their career planning to conduct our empirical study. Univariate analysis is applied in analyzing the differences of variables between the two groups. To conduct multivariate analysis of relationship between performance in accounting learning and factors that may influence the performance, we calculate our regression by using the following equation:

$$
I^{\prime} A I_{t_{t}, t}=\beta_{\mathrm{v}}+\beta_{1} E A_{t_{t}, t}+\beta_{2} M V_{t, t}+\beta_{3} A A_{t_{t}, t}+\beta_{4} \text { ciender }_{t_{t}, t}+\varepsilon_{t_{t}, t}
$$

where TAP stands for term accounting performance, measured by the assessment score consisting of two quizzes, one case report and the final exam. LA is a dummy variable and equals to 1 for the students of English major and 0 for the students of non-English major on the dual bachelor degree program. MV measures students' motivation in studying the accounting related courses. The students' intention to take an accounting job as career goal is used as the proxy for motivation. The 5-level Likert Scale is applied in measuring the strength of motivation where 5 means "I will take an accounting-related job when graduated" and 1 means "I will not take an accounting-related job when graduated". Two through four then represents "disagree", "neither agree nor 
disagree" and "agree" respectively. AA represents students' analytical ability. Gender is a dummy variable and is 0 for male and 1 for female. We test $\mathrm{H} 2$ and $\mathrm{H} 4$ by estimating equation (1) and expect the coefficient of LA to be insignificant and MV and AA to be significantly positive.

To further analyze the factors that influence their performance, we break down the case study report into three parts: reading, writing and analysis. The final case report score is given based on the previously mentioned allocation ratio. Thus, we have the following modified regression equation:

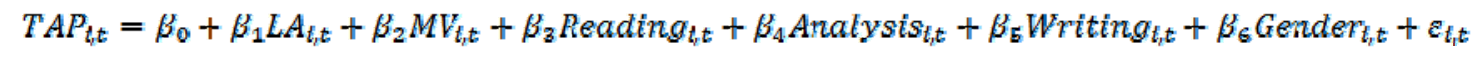

where reading, writing and analysis represent the respective score from the case report submitted at the end of semester. We expect the coefficient of analysis to be significantly positive in testing $\mathrm{H} 2$.

\section{Empirical Results}

\subsection{Summary Statistics}

Table 1 presents the summary statistics for term accounting performance, reading, analytical skills as well as other variables. As can be seen from Panel A of Table 1 for all the sample, the average term accounting score is 85.6. We also present the average motivation at 3.823 and the mean scores in reading, writing and analytical skills are 5.112, 5.042 and 13.471 respectively. In Panels B and C, we summarize the statistics for both English majors and non-English majors. We find 3.557 differences in the term accounting score between the two groups. Other variables also present some differences which will be analyzed in our univariate tests and will be included as control variables in our regression analysis.

Table 1. Summary statistics

\begin{tabular}{llllll}
\hline $\begin{array}{l}\text { Panel A: All sample } \\
\text { Variables }\end{array}$ & Observations & Mean & Standard Deviation & Min. Value & Max. Value \\
\hline TAP & 1,104 & 85.600 & 20.055 & 50.000 & 98.000 \\
LA & 1,104 & 0.480 & 0.010 & 0.470 & 0.500 \\
MV & 1,104 & 3.823 & 1.442 & 1.000 & 5.000 \\
AA & 1,104 & 24.661 & 3.683 & 18.000 & 30.000 \\
Gender & 1,104 & 0.693 & 0.060 & 0.000 & 1.000 \\
Reading & 1,104 & 5.112 & 0.835 & 3.500 & 6.000 \\
Analysis & 1,104 & 13.471 & 2.737 & 10.000 & 18.000 \\
Writing & 1,104 & 5.042 & 0.811 & 3.000 & 6.000
\end{tabular}

Panel B: Non-English majors on the dual bachelor degree program

\begin{tabular}{llllll}
\hline TAP & 585 & 84.031 & 18.033 & 50.000 & 98.000 \\
LA & 585 & 0.000 & 0.000 & 0.000 & 0.000 \\
MV & 585 & 4.382 & 0.485 & 3.000 & 5.000 \\
AA & 585 & 27.501 & 2.834 & 24.000 & 30.000 \\
Gender & 585 & 0.601 & 0.052 & 0.000 & 1.000 \\
Reading & 585 & 4.987 & 1.203 & 3.500 & 6.000 \\
Analysis & 585 & 16.239 & 1.850 & 14.000 & 18.000 \\
Writing & 585 & 3.504 & 2.343 & 3.000 & 6.000
\end{tabular}

Panel C: English majors from SEIB, Guangdong University of Foreign Studies

\begin{tabular}{llllll}
\hline TAP & 519 & 87.588 & 23.067 & 63.000 & 98.000 \\
LA & 519 & 1.000 & 1.000 & 1.000 & 1.000 \\
MV & 519 & 3.173 & 2.143 & 1.000 & 5.000 \\
AA & 519 & 21.358 & 3.232 & 18.000 & 30.000
\end{tabular}




$\begin{array}{llllll}\text { Gender } & 519 & 0.800 & 0.798 & 0.000 & 1.000 \\ \text { Reading } & 519 & 5.257 & 0.586 & 4.000 & 6.000 \\ \text { Analysis } & 519 & 10.252 & 3.847 & 10.000 & 18.000 \\ \text { Writing } & 519 & 6.831 & 0.284 & 4.000 & 6.000\end{array}$

This table presents summary statistics of all variables in our study. Measurement of these variables are stated in Section 4.2.

\subsection{Univariate Tests}

To provide some empirical evidence to support our hypotheses, we conduct univariate tests by comparing the average term accounting performance and other variables between English major and non-English major students, with the results shown in Table 2. In particular, the mean scores of Term Accounting Performance are 84.031 and 87.588 respectively, with a difference of 3.557. However, the difference is insignificant at each level. As noted in the data description, the only main big gap between the two groups is the curriculum design in which students of English major are required to receive intensive English language training before taking the Introduction to Accounting course while the those of non-English major don't need to, so the statistical insignificant difference implies that this main gap between the two groups doesn't cause any significant difference in their accounting learning and language in this context doesn't matter much. We also notice a mean difference of -0.270 and median difference of -1.000 in reading, and a mean difference of -3.327 and median difference of -2.000 in writing, both significant at $5 \%$ level. These results suggest that the intensive language training for English majors has a positive effect on students' language proficiency. Compared with the experiment group, the control group has higher competence in English writing and reading. However, we find that non-English majors outperformed English majors in analytical skills, with a difference of 5.987 at $1 \%$ significant level. This might imply that the students from across the University rather than from SEIB were better at science courses than English in their high school (as more weight might have been given to their scores on science subjects when they applied for the University through Gaokao) or it might imply that they received more training in science courses than in language in their first two years of university. It is worth noting that we have observed a 1.209 difference in motivation, at $1 \%$ significant level. This suggests that the students on the dual-bachelor degree program have a clearer career path than students of English major. Overall, the results from Table 2 lend support to our hypotheses that there is no direct significant relationship between accounting learning in tertiary education and students' English proficiency and the factors that may influence accounting study in English would be others, such as students' motivation and analytical skills.

Table 2. Univariate tests

\begin{tabular}{llllllll}
\hline Variables & Mean & \multicolumn{5}{l}{ Median } \\
\cline { 2 - 3 } \cline { 6 - 7 } & Non-English majors & English majors & Difference & & Non-English majors & English Majors & Difference \\
\hline TAP & 84.031 & 87.588 & -3.557 & & 72.000 & 78.000 & -6.000 \\
LA & 0.000 & 1.000 & $-1.000^{* * *}$ & & 0.000 & 1.000 & $-1.000^{* * *}$ \\
MV & 4.382 & 3.173 & $1.209^{* * *}$ & & 4.000 & 3.000 & $1.000^{* * *}$ \\
AA & 27.501 & 21.358 & $6.143^{* *}$ & & 23.000 & 20.000 & $3.000^{* *}$ \\
Gender & 0.601 & 0.800 & -0.199 & & 0.601 & 0.800 & $-0.199^{*}$ \\
Reading & 4.987 & 5.257 & $-0.270^{* *}$ & & 4.000 & 5.000 & $-1.000^{* *}$ \\
Analysis & 16.239 & 10.252 & $5.987^{* * *}$ & & 15.000 & 12.000 & $3.000^{* *}$ \\
Writing & 3.504 & 6.831 & $-3.327^{* *}$ & & 4.000 & 6.000 & $-2.000^{*}$ \\
\hline
\end{tabular}

This table reports the mean and median value of variables described in Section $4 . *, * *, * * *$ indicate significance at $10 \%, 5 \%$ and $1 \%$ levels respectively.

\subsection{Term Accounting Performance and Its Influencing Factors}

In this section, we perform regression analysis to examine what influence students' accounting performance when it is taught in English by estimating Equation (1) and Equation (2) and report the results in Table 3. 
Column 1 and Column 2 present the results for all the sample while Column 2 breaks down the analytical ability (AA) into three parts: reading, analysis and writing. We observe a great $F$ value of 73.975 with significant level at $1 \%$, indicating that the overall model is valid. We also notice that the adjusted $\mathrm{R}$ square after considering time fixed effects is greater than $20 \%$, suggesting that our regression model fits and the independent variables in our model can explain the dependable variable $\mathrm{Y}$, which is term accounting performance in our case. Across two specifications, we find that the estimated coefficients on $L A$ are all positive but insignificant. This result suggests that the final assessment score is higher for English majors than for non-English majors but the difference is not significant. This finding is consistent with our hypothesis $\mathrm{H} 1$ that there is no direct significant relationship between accounting learning at university level and students' English proficiency.

We also find that the estimated coefficients on $M A$ are all positive and statistically significant at $1 \%$ level, lending support to our $\mathrm{H} 4$ that the stronger the intrinsic motivation is, the better the students will perform in their business related course study instructed in English.

In Column 1, we notice that every one more credits earned in case analysis report brings about 1.639 more credits to final assessment score, and the result is statistically significant at $1 \%$ level. When the analytical ability is broken down into three parts as shown in Column 2, we find that the results are consistent with those in Column 1. Reading, analysis and writing are all positively correlated with final assessment at $1 \%$ significant level. These results support our hypothesis $\mathrm{H} 2$ that there is a strong correlation between students' analytical ability and accounting learning performance instructed in English.

The gender effect is not stable and the result is insignificant in both columns, indicating that gender doesn't matter in the accounting learning instructed in English.

Table 3. The effect of English proficiency, motivation, analytical ability on Term accounting performance

\begin{tabular}{lll}
\hline & $(1)$ & $(2)$ \\
& TAP & TAP \\
\hline Constant & $-0.772^{* * *}$ & $-1.271^{* * *}$ \\
LA & $(0.032)$ & $(0.045)$ \\
MV & 4.323 & 4.284 \\
& $(2.701)$ & $(2.596)$ \\
AA & $2.904^{* * *}$ & $3.070^{* * *}$ \\
& $(0.053)$ & $(0.062)$ \\
Reading & $1.639^{* * *}$ & \\
& $(0.019)$ & \\
Analysis & & $0.609^{* * *}$ \\
Writing & & $(0.007)$ \\
Gender & & $0.714^{* * *}$ \\
Time Fixed Effects & & $(0.001)$ \\
F test & & $0.314 * * *$ \\
$\mathrm{R}^{2}$ & & $(0.001)$ \\
Adj. $\mathrm{R}^{2}$ & & 0.002 \\
Observations & & $(1.203)$ \\
\hline
\end{tabular}

The dependent variable is Term accounting performance, denoted by the term assessment score. T-statistics are in parentheses, ${ }^{*}, * *, * *$ indicate significance at $10 \%, 5 \%$ and $1 \%$ levels respectively. 


\section{Conclusion}

Immersion teaching has attracted considerable attention worldwide and immersion teaching in English is attracting more and more attention in China, especially at tertiary level. In this study, the authors take as objects of study the program of the School of English for International Business, GDUFS designed to teach its students business related courses in English and the dual program that provides the same curriculum to students of non-English major from other schools campus-wide to closely examine the role language proficiency plays in understanding the content of accounting course and to investigate what may influence accounting learning. Unlike similar studies in China, the sample size in this study is larger, covering 1104 students with a span of seven years. In addition, the sample collection avoids the heteroscedasticity issue since the backgrounds of the two groups are similar and their accounting course is taught by the same teacher using the same textbooks and teaching methodology.

Consistent with our predictions, we find that there is no direct significant relationship between accounting learning and students' English proficiency at tertiary level and we also find that what influence students' performance are their analytical skill and attitude. In the current literature, there are arguments about whether English Immersion Teaching is feasible since students' level of English varies. Our results reveal that it is feasible to carry out English Immersion Teaching to college students, be the English major or not. Our research contributes to the current literature in its empirical way and it has some useful implications for higher education policy makers. On the one hand, it is desirable for the Ministry of Education to encourage the colleges and universities to implement English Immersion teaching of business related courses. On the other hand, the government is expected to design a good learning environment in English educational settings and to provide useful resources to higher education.

In this paper, we have not discussed the teacher's role in English Immersion Teaching though we believe that the teacher is a critical key to the success of immersion teaching. Moreover, the sample in our study is collected from one university and we understand that students from other universities of various categories in China may be very different in their educational background, learning ability, English proficiency and so on but we have not explored the cut-off point beyond which the language of instruction doesn't make any difference. These two issues may be good candidates for our further study down the road.

\section{References}

Bae, J. (2011). A 15-minute summary in Korean: English lectures at Korean universities. The Money Today, 2011-06-01.

Cai, J. G. (2010). On the Relationship between English Language Skills Training and the Development of Critical Thinking. Foreign Languages in China, 7(6), 61-68.

Cai, Y. (2005). The Design and Implementation of English Immersion Approach: Evaluation of BBA Program of GDUFS. International Economics \& Trade Research, 21, 4-8

Chang, L., \& Liu, Z. H. (2014). A Study of the Effects of Undergraduate Immersive English Teaching: Evidence from GDUFS. Journal of Guangdong University of Foreign Studies, 4, 83-86.

Chen, Y. F., \& Xu, L. (2009). Investigation and Analysis on Teacher's Ability of Teaching with Immersion English. Future and Development, 30(6), 91-93

Cummins, J. (1983). Language Proficiency, Biliteracy and French Immersion. Canadian Journal of Education, 8(2), 117-138. https://doi.org/10.2307/1494722

Duan, D. Y. (2017). Discussion on the Teaching Theory of English Immersion Teaching in China. Higher Architectural Education.

Du, F. F. (2005). On the roles of instructors conducting the English Immersion Teaching. International Economics and Trade Research, 21, 70-72.

Gagné, M., \& Deci, E. L. (2005). Self-determination theory and work motivation. Journal of organizational behavior, 26, 331-362. https://doi.org/10.1002/job.322

Genesee, F. (1985). Second language learning through immersion: A review of U.S. programs. Review of Educational Research, 55, 541-561. https://doi.org/10.3102/00346543055004541

Grabe, W., \& Stoller, F. L. (1997). Content-based instruction: Research foundations.

Guo, G. H. (2007). Strategies in Adopting English Immersion Approach in Teaching Business courses. Journal of Guangdong University of Foreign Studies, 18(5), 63-66. 
$\mathrm{Hu}, \mathrm{X}$. L. (2006). Some issues and suggestions on teachers' qualification in English Immersion Teaching. China Higher Education in Medical Science, 11, 51-52.

Jimenez, C., Blanchard, J., \& Atwill, K. (2014). Beginning English Literacy Development and Achievement among Spanish - Speaking Children in Arizona's English-Only Classrooms: A Four- Year Two- Cohort Longitudinal Study. International Multilingual Research Journal, 8(2), 104-123. https://doi.org/10.1080/19313152.2013.875812

Kang, H. S. (2012). English-only instruction at Korean universities: Help or hindrance to higher learning? English Today, 28(01), 29-34. https://doi.org/10.1017/S0266078411000654

Likert, S. (1932). A Technique for the Measurement of Attitudes. Archives of Psychology, 140, 1-55.

Macaroe, L. J. H. (2013). Teacher Language Background, Codeswitching, and English- Only Instruction: Does Age Make a Difference to Learners' Attitudes? Tesol Quarterly, 47, 717- 742. https://doi.org/10.1002/tesq.74

Met, M. (1999). Making connections. In J. K. Phillips, \& C. R. M. Terry (Eds.), Foreign language standards: Linking research, theories and practices (pp. 137-164).

Ratelle, C. F., Vallerand, R. J., Mageau, G. A., Rousseau, F. L., \& Provencher, P. (2004). When passion leads to problematic outcomes:A look at gambling. Journal of Gambling Studies, 20(2), 105-119. https://doi.org/10.1023/B:JOGS.0000022304.96042.e6

Rea Dickins, P., \& Yug. (2013). English Medium Instruction and Examining in Zanzibar. Language Issues in Comparative Education. Sense Publishers. https://doi.org/10.1007/978-94-6209-218-1_11

Snow, M. A. (1986). Innovative Second Language Education: Bilingual Immersion Programs (ReportEvaluative/Feasibility 142): UCLA. Center for Language Education and Research.

Snow, M. A., Met, M., \& Genesee, F. (1989). A conceptual framework for the integration of language and content in second/foreign language programs. TESOL Quarterly, 23, 201-217. https://doi.org/10.2307/3587333

Snow, D., \& Brinton, M. (2005). The content-based classroom: Perspectives on integrating language and content. (pp. 5-21). White Plains, NY: Longman.

Swain, M. (1996). Integrating language and content in immersion classrooms: Research perspectives. The Canadian Modern Language Review, 52,529-548.

Tice, D. M., Baumeister, R. F., Shmueli, D., \& Muraven, M. (2007). Restoring the self: Positive affect helps improve self-regulation following ego depletion. Journal of Experimental Social Psychology, 43(3), 379-384. https://doi.org/10.1016/j.jesp.2006.05.007

Wang, L. Z., Xu, Y. C., \& Ai, W. (2015). Factors that Influence the English Immersion Teaching. Course Education Research, (4), 218.

Xing, X. L. (2006). Examing the Effects of Bilingual Teaching Effects and Some Suggestions. Statistics and Information, (6), 15-18.

\section{Copyrights}

Copyright for this article is retained by the author(s), with first publication rights granted to the journal.

This is an open-access article distributed under the terms and conditions of the Creative Commons Attribution license (http://creativecommons.org/licenses/by/4.0/). 